\title{
Review
}

\section{Influence of Heat Treatment and Microfiltration on the Milk Proteins Properties}

\author{
Silvani Verruck, PhD'*; Saionara Sartor, PhD'; Flávia Buss Marenda, PhD'; Eulália Lopes da Silva Barros, MSc²; \\ Callebe Camelo-Silva, MSc'2; Maria Helena Machado Canella, PhD'; Elane Schwinden Prudencio, PhD ${ }^{1,2}$ \\ 'Department of Food Science and Technology, Federal University of Santa Catarina (UFSC), Agricultural Science Center, Florianópolis, Santa Catarina, Brazil \\ ${ }^{2}$ Department of Chemical and Food Engineering, Federal University of Santa Catarina (UFSC), Technological Center, Florianópolis, Santa Catarina. Brazil
}

\section{"Corresponding author}

Silvani Verruck, PhD

Department of Food Science and Technology, Federal University of Santa Catarina (UFSC), Agricultural Science Center, Florianópolis, Santa Catarina, Brazil; E-mail: silvani.verruck@gmail.com

\section{Article information}

Received: April 24 $4^{\text {th }}, 2019$; Revised: June $4^{\text {th }}, 2019$; Accepted: June $6^{\text {th }}$, 2019; Published: June $14^{\text {th }}, 2019$

\section{Cite this article}

Verruck S, Sartor S, Marenda FB, et al. Influence of heat treatment and microfiltration on the milk proteins properties. Adv Food Technol Nutr Sci Open J. 2019; 5(2): 54-66. doi: 10.17|40/AFTNSOJ-5-157

\section{ABSTRACT}

Heat treatments are the established food technology for commercial processing of milk. However, degradation of valuable nutrients in milk (as proteins) and its sensory characteristics occur during these processes due to substantial heat exposure. The most important reactions that occur during milk heat treatment are the whey proteins denaturation, its interactions with the casein micelles and aggregation/dissociation of the casein micelles. Microfiltration represents an emerging food processing technology allowing gentle milk preservation at lower temperatures for similar, or better, nutritive value, microbial removal, and shelf stability. Thus, the aim of this work is to review the existing studies on the effects of microfiltration on milk proteins by comparing with the effects of heating treatments.

\section{Keywords}

Microfiltration; Heat treatment; Milk proteins.

\section{INTRODUCTION |}

$\mathrm{T}$ he proteins are important constituents of the human diet since they are the principal source of nitrogen and essential amino acids. The properties and functionality of the protein depend on its amino acid composition and arrangement of the peptide bonds that stabilize the structure. ${ }^{1}$ The functional properties of the proteins are related to various general characteristics such as molecular moisturizing, surface activity and type of protein-protein interactions, facilitated by the partial unfolding of structures. ${ }^{2}$ Milk proteins play an important role as functional ingredients in foods, acting as emulsifying, foaming and gelling agents. ${ }^{3}$

Milk is a complex food from a molecular composition perspective which constitutes an important part of a human's diet, mainly because of its high nutritional value. Milk consists of various protein fractions, such as casein micelles and several whey proteins with different molecular weights. ${ }^{4}$ Caseins representing approximately $80 \%$ of the total protein fraction in milk. These proteins have excellent surfactant properties in emulsions and foams, gelling properties, and thermal resistance to denaturation ${ }^{5}$ because of their lack of complex secondary and tertiary structure. However, the casein micelles are composed of the proteins $\alpha \mathrm{S} 1$-, $\alpha \mathrm{S} 2-, \beta$-, and $x$-caseins, and salts of $\mathrm{Ca}, \mathrm{P}, \mathrm{Mg}$, and $\mathrm{Zn} .{ }^{1} \mathrm{In}$ fresh milk, the caseins are present in the form of essentially spherical particles containing many protein molecules and amorphous calcium phosphate; these particles have in average $150 \mathrm{~nm}$ of diameter with sizes ranging from 15 to about $1000 \mathrm{~nm}$ in diameter. Apart from $x$-casein, which is mostly found on/or near the external surface of the micelle, the caseins appear to be more or less evenly distributed within the micelle. ${ }^{6}$ Casein micelles are in colloidal suspension in milk and are approximately 100 times larger than whey proteins $(0.003$ to $0.010 \mu \mathrm{m})$, which are soluble in milk. ${ }^{7}$ However, the whey proteins are typical globular, highly structured proteins, most of which have been isolated, crystallized, and well characterized. The lactoglobulin fraction contains immunoglobulins G, A, and $\mathrm{M}$, which are present at very high-levels in colostrum and play very important protective roles. The lactalbumin fraction contains two main proteins, $\alpha$-lactalbumin and $\beta$-lactoglobulin, and several minor proteins, including blood serum albumin, lactoferrin, and vitamin-binding proteins; it contains several peptide hormones and about 70 enzymes. ${ }^{1}$ 
Heat treatment can damage the biological properties of milk components, impair protein availability, and promote intolerance and allergy. ${ }^{5,7} \mathrm{It}$ is now well established that high-temperature processing, especially ultra-high temperature (UHT), causes a series of effects on milk such as loss of available lysine, ${ }^{8,9}$ and aggregation and denaturation of protein. ${ }^{10-13}$ As a result, many chemical changes could also occur, ${ }^{14-16}$ in addition to modifications on functional properties of milk proteins. ${ }^{6}$ These changes inevitably affect the renneting, emulsifying, and foaming properties of the dairy products based on the processed milk. ${ }^{17-20}$

The rise of alternative technologies, such as microfiltration, can help prevent these problems while also assuring food safety. Membrane processes are increasingly used in the dairy industry for bacteria removal by microfiltration. ${ }^{21}$ Microfiltration (MF) has gained significant attention in recent years as a processing method for the removal of microorganisms from milk. ${ }^{22-29}$ With the advancement of membrane filtration technology, the use in the dairy industry has become more technically and economically feasible. ${ }^{30-32}$ Furthermore, the MF process may preserve the bioavailability of the thermosensitive and active milk components, such as bioactive peptides, vitamins, and antioxidants. However, works that studied the effects of the microfiltration processes on milk proteins properties are scarce.

Therefore, this work aims to review the existing studies on the effects of milk microfiltration on milk proteins by comparing with the effects of heating treatments, like pasteurization and UHT technology. In other words, our work aims to review the application of milk microfiltration technology to obtain milk with better safety and quality which does not have its original features transformed by thermal processes.

\section{Proteins Functional Properties}

The functionality of food proteins refers to the physical and chemical properties that influence the performance of the proteins of food systems during processing, storage, preparation, and consumption. These characteristics influence the quality and sensory characteristics of food. ${ }^{2}$ The functional properties of food proteins can be classified into three main groups: hydration properties, which are dependent on protein-water interactions (water absorption and retention, wettability, swelling, adhesion, dispersibility, solubility and viscosity); properties that are related to protein-protein interactions (precipitation and gelation); and surface properties (surface tension, emulsification and foaming characteristics). ${ }^{33}$

Defining and measuring protein functionality starts at the level of protein structure. A simple model for protein denaturation is:

$$
\mathrm{N} \leftrightarrow \mathrm{I} \rightarrow \mathrm{D}
$$

In this model, a native $(\mathrm{N})$ structure is reversibly converted to an intermediate (I) state where the tertiary structure is changed but much of the secondary structure remains, and further unfolding produces a denatured (D) state. There are various molecular properties associated with each state that have an impact on functional properties (Table 1). According to Foegeding and Davis, ${ }^{34}$ molecular weight and primary structure will not be changed during the denaturation process and are considered constants. The isoelectric point can vary due to intermediate and denatured (unfolded) structures exposing charged amino acids to new local environments. The main changes are in a secondary and tertiary structure that can alter the surface exposure of amino acids. This cumulates in an increase in interaction potential, favoring aggregation, and the loss of structural epitopes for allergenicity. Therefore, determining the specific structural transitions during folding/unfolding for food proteins is essential to understand the molecular basis of functionality. ${ }^{34}$

Milk proteins are commonly used as food ingredients in food products not only for their nutritional properties but also for their functional and technological characteristics. ${ }^{35}$ Milk proteins have a high nutritional value compared to other proteins, because

\begin{tabular}{|c|c|c|c|}
\hline $\begin{array}{l}\text { Properties of the } \\
\text { native state }\end{array}$ & Key factors & Change in $\mathrm{N} \longrightarrow \mathrm{I}$ & Change in $I \longrightarrow D$ \\
\hline Molecular weight & Determines general polymer properties & No & No \\
\hline Isoelectric point & Determines phase stability & $\begin{array}{l}\text { Possible due to altered } \\
\mathrm{pK}_{\mathrm{a}} \mathrm{s} \text { of functional groups }\end{array}$ & $\begin{array}{l}\text { Possible due to altered } \mathrm{pK}_{\mathrm{a}} \mathrm{s} \\
\text { of functional groups }\end{array}$ \\
\hline \multirow{3}{*}{ Primary structure } & $\begin{array}{l}\text { Sequence of non-polar, polar and } \\
\text { charged amino acids }\end{array}$ & No & No \\
\hline & Sequential epitopes & No & No \\
\hline & Bioactive peptides & No & No \\
\hline $\begin{array}{l}\text { Secondary } \\
\text { structure }\end{array}$ & $\begin{array}{l}\text { Amount of } \alpha \text {-helix, } \beta \text {-sheets and other } \\
\text { structures }\end{array}$ & Very little & Yes \\
\hline \multirow{2}{*}{ Tertiary structure } & Overall structure & Yes & Yes \\
\hline & Structural epitopes & Yes & Yes \\
\hline Surface topology & $\begin{array}{l}\text { Groupings of non-polar, polar and } \\
\text { charged amino acids in } \\
\text { surface-assessable space }\end{array}$ & Yes & Yes \\
\hline
\end{tabular}


of their relatively high content of essential amino acids and better digestibility. ${ }^{1}$ Milk consists of various protein fractions: casein micelles (d 50, 3=180 nm, isoelectric point: $\mathrm{pH} 4.6$ ) and several whey proteins with different molecular weights $(\mathrm{d}=2-6 \mathrm{~nm}$, isoelectric point: $\mathrm{pH} \sim 5)^{4}$

\section{Casein Functional Properties}

Caseins are one of the most important and complex proteins in milk. These proteins have excellent surfactant properties in emulsions and foams, gelling properties, and thermal resistance to denaturation ${ }^{5}$ because of their lack of complex secondary and tertiary structure. However, the casein micelles are composed of four individual gene product component, denoted $\alpha \mathrm{S} 1_{-}^{-}, \alpha \mathrm{S} 2-, \beta-$, and $x$-caseins, which differ in primary structure, type and degree of post-translational modification, and salts of $\mathrm{Ca}, \mathrm{P}, \mathrm{Mg}$, and $\mathrm{Zn} .{ }^{35}$ The remainder of the micellar solids consists of inorganic material, collectively referred to as colloidal calcium phosphate (CCP) or micellar calcium phosphate (MCP). ${ }^{36}$ Casein micelles (0.02 to $0.40 \mu \mathrm{m}$ in diameter) are in colloidal suspension in milk, and are approximately 100 times larger than whey proteins $(0.003$ to $0.010 \mu \mathrm{m}$ ), which are soluble in milk. ${ }^{7}$

The internal structure of a casein micelle consists of a protein matrix in which calcium phosphate nanoclusters are dispersed (Figure 1). Attached to the surface of the nanoclusters are the centers of phosphorylation (nearby 3-5 phosphorylated amino acid residues) of the caseins. The tails of the caseins, much larger than the CCP clusters, then associate to form a protein matrix, which can be viewed as polymer mesh. The association of the tails is driven by a collection of hydrophobic interactions (weak interactions). The association is highly cooperative and originates in the weak interactions. It is the cooperative that leads to a stable casein micelle. Invariably, k-casein is thought to limit the process of self-association leading to stabilization of the native casein micelle. ${ }^{36}$

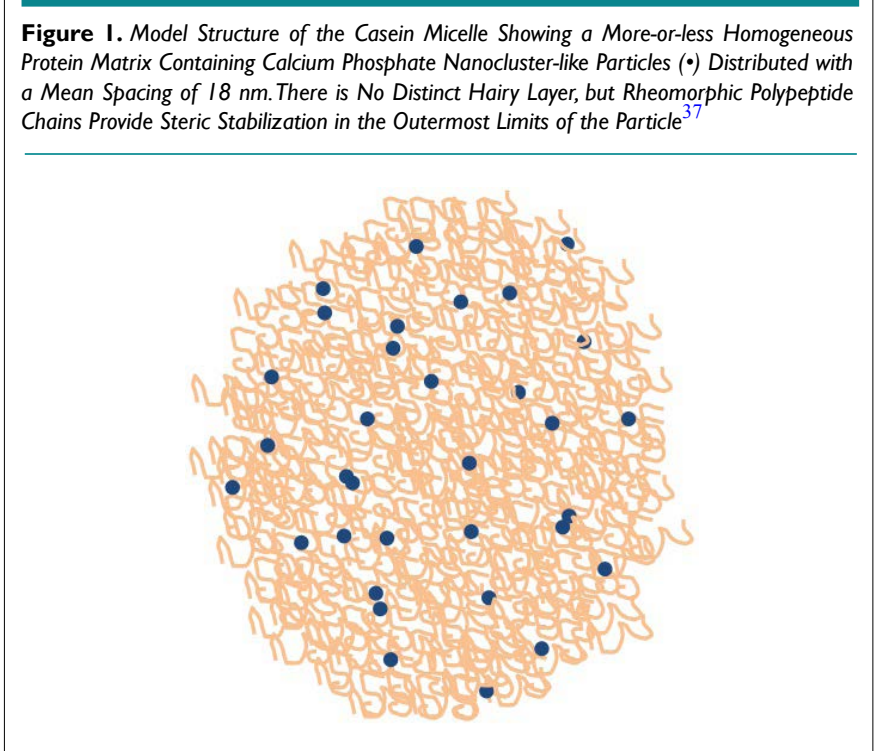

Caseins exhibit specific interactions with calcium ions and salts. Because of their primary structures and specific tertiary, these proteins undergo post-translational phosphorylation. ${ }^{35,37}$ This modification results in the formation of anionic clusters of the calcium-sensitive casein while a single residue is phosphorylated in k-casein, which is insensitive to calcium. The calciumsensitive caseins, $\alpha$ s1-, $\alpha$ s 2 - and $\beta$-caseins are so called because of its extremely low solubility in the presence of $\mathrm{Ca}^{2+} \cdot{ }^{38} \mathrm{It}$ is very probable that these caseins have evolved from a common ancestral gene, while the $\mathrm{k}$-casein has arisen from a different gene. ${ }^{35}$

Casein has a long history as essential ingredients for food and due to its open and flexible structure, caseins have different functionality. It can be widely used in several kinds of products. ${ }^{1}$ The casein has excellent solubility and thermal stability at $\mathrm{pH}$ above $6 .^{35}$ Moreover, due to their amphiphilic structure, these proteins are useful for emulsifying, water binding, thickening, creaming/foam, and gel formation. ${ }^{2,38}$ The products based on commercial casein available as food ingredients are acidic casein, casein obtained by enzymatic coagulation, caseinates and coprecipitates. ${ }^{35}$ The functionality of these commercial products depends on the type of food in which they are added. ${ }^{35}$

One of the simplest ways to alter the functionality of the proteins is by mild heat treatments that alter protein structure and cause aggregation but do not result in large scale protein precipitation. ${ }^{34}$ Denaturation controlled or partial during various isolation steps is generally desirable, as it helps in maintaining an acceptable protein solubility, which is often a prerequisite for the functionality of these proteins in food products. ${ }^{2}$

Proteins are often isolated using isoelectric precipitation. The casein micelles are destabilized irreversibly by isoelectric precipitation. ${ }^{38}$ These collapses of the micellar structure of casein are due to several factors, including the solubility of colloidal calcium phosphate and the change in the balance of hydrophobic and electrostatic interactions between different types of casein. ${ }^{39}$ The composition of the precipitated proteins usually changed, compared with materials in their native form. These changes at the molecular level may have an impact on protein functionality. ${ }^{39}$

Studies have shown the relationship between the structure of the casein modified by the processing and its functionality. ${ }^{33,40-42}$ According to Raikos ${ }^{39}$ the degree of protein denaturation induced by heat treatment, under the given chemical environment, was concluded to be the key factor which determines the interfacial functionality of milk proteins with subsequent effects on the emulsion properties. In these and other modifications, i.e., Maillard type reactions to form protein/sugar adjuncts, deamidation, enzymatic crosslinking or enzymatic hydrolysis, usually alter the functionality of the protein. ${ }^{34}$

\section{Whey Proteins Functional Properties}

Whey proteins constitute $20 \%$ of the proteins in milk and represent an excellent source of functional proteins of high nutritional value. ${ }^{35}$ The most important are the globular proteins $\beta$-lactoglobulin ( $\beta$-LG; approximately $3.2 \mathrm{~g} / \mathrm{L}$ ) and $\alpha$-lactalbumin 
( $\alpha$-LA; approximately $1.2 \mathrm{~g} / \mathrm{L}$ ), representing 70 to $80 \%$ of the whey proteins. Besides these, the whey also contains serum albumin (BSA; approximately $0.4 \mathrm{~g} / \mathrm{L}$ ) and immunoglobulins (Ig; approximately $0.7 \mathrm{~g} / \mathrm{L}$ ), which are derived from blood. ${ }^{39}$ Whey proteins are very desirable as nutritional ingredients due to its high concentration of sulfur amino acids. ${ }^{35}$

$\beta$-Lactoglobulin is a globular protein with a monomer molecular weight of $18.4 \mathrm{kDa}$ and accounts for about $50 \%$ of the protein in bovine whey isolate. The secondary structure is composed of $16 \% \alpha$-helix, $58 \% \beta$-sheet and $25 \%$ random coil. 35 Native $\beta$-LG has nine strands that are folded into two $\beta$-sheets: sheet 1 contains strands $B, C$ and $D$, and part of strand A (A1); sheet 2 contains strands E, F, G and H, part of strand A (A2) and strand I. One side of sheet 1 is hydrophobic and the other side is hydrophilic. Sheet 2 is also hydrophobic on one side and faces the hydrophobic side of sheet 1 , thus creating a very hydrophobic cavity, which is nevertheless filled with water. There is also another hydrophobic region on the side of sheet 2 , where the three-turn helix lies above it and along strands F, G and H. $\beta$-LG has two disulfide bonds and one free $\mathrm{Cys}(\mathrm{CysH}){ }^{43}$

The $\alpha$-LA accounts for about $20 \%$ the protein in bovine whey, has a molar mass of $14.2 \mathrm{kDa}$, and is stabilized by four disulfide bonds and does not contain a free thiol group. However, one of the disulfide bonds (Cys6-Cys120) is more sensitive to cleavage than the other three because of its lower inherent stability. ${ }^{44}$ The protein also exists in a number of environment-dependent conformations, including the holo (native, calcium-bound) form, which is the major form in milk. ${ }^{43}$

The BSA is a single polypeptide of 582 amino acid residues with a molecular weight of $66,433 \mathrm{Da}$ and exists in a multidomain structure with complex ligand-binding specificities. ${ }^{43}$ It is characterized by an overall oblate shape and consists of three domains (I, II and III), each stabilized by an internal network of disulfide bonds. The primary structure has 17 disulfide bridges that hold the molecule in a structure consisting of nine loops. It contains one free thiol group, Cys34. The secondary structure is composed of $76 \%$ helix, $10 \%$ turn, and $23 \%$ extended chain, and no $\beta$-sheet. ${ }^{2}$

Whey protein denaturation is one of the main effects of milk heating which causes modification on the chemical and nutritional properties. ${ }^{45}$ The concentration or isolation of whey protein, which represent excellent functionality and nutritional properties, is economically feasible for use as the basis of many dairy products, cheese, and other protein ingredients. ${ }^{35}$ Whey protein ingredients are used for a variety of functional applications in the food industry. ${ }^{3,46-48}$ The milk proteins and particularly whey proteins are commonly used as emulsifying and foaming agents in diverse food products thanks to their unique interfacial properties. $^{49}$

Unlike the caseins, whey proteins are unstable to heat and this influences the physical and chemical properties of milk products. ${ }^{43}$ On the other hand, the manufacture of most dairy products involves heat treatment. ${ }^{35}$ Studies have been conducted on the mechanism of denaturation and aggregation of whey proteins during heating and on ways of preventing such changes which are critical to improving their stability. ${ }^{45}$

\section{Effects of Heat Treatments on Milk Proteins Structure}

Heat treatment of milk and milk products is an essential operation in commercial dairy processes in order to provide acceptable safety and shelf life. ${ }^{50}$ The most important reactions that occur during milk heat treatment are the whey proteins denaturation, its interactions with the casein micelles and aggregation/dissociation of the casein micelles. ${ }^{51}$ Denaturation alters several important properties of proteins from the viewpoint of food technology. The denatured protein is generally less soluble or even insoluble, promotes an increase in feed viscosity and the reactivity of their side groups are intensified. ${ }^{2}$

The denaturation also affects the three-dimensional conformation and functional characteristics of the milk proteins besides the degree of heat denaturation varies depending on the intensity of the thermal treatment applied. ${ }^{35}$ Changes in protein conformation can affect the thermodynamics of binding with water because they may change the availability of polar sites or hydration sites. The transition from the compact globular conformation of the protein molecule for random conformation can result in an increase of the available surface area and exposure peptides and amino acid side chains. ${ }^{52}$

Among the milk proteins, whey proteins are the most thermolabile. As been described in the literature, susceptibility of whey proteins to heat denaturation results from their high level of secondary and tertiary structure..$^{35,43,53-55}$ Because denaturation of whey proteins occurs rapidly at temperatures above $70{ }^{\circ} \mathrm{C}$, commercial heat treatments denature at least a portion of these proteins. ${ }^{35}$ The functionality of whey proteins is very sensitive to the extent of denaturation. Major whey proteins exhibit thermostability to structural unfolding in the order $\alpha$-lactalbumin $<$ al bumin $<$ immunoglobulin $<\beta$-lactoglobulin. However, the thermal unfolding of $\alpha$-lactalbumin is reversible so that denaturation, as measured by irreversible changes, indicates an order of increasing the thermostability of $\operatorname{IgG}<$ serum albumin $<\beta$-lactoglobulin $<$ $\alpha$-lactalbumin. ${ }^{56,57}$ The thermal behavior of the whey proteins is ruled primarily by the properties of $\beta$-lactoglobulin, which are affected by the $\mathrm{pH}$, lactose, sodium chloride, calcium, and other ions. ${ }^{58}$ In particular, $\beta$-lactoglobulin and serum albumin command protein aggregation via thiol-disulfide exchange and oxidation-reduction reactions during the heat treatment. ${ }^{55}$ Swais$\operatorname{good}^{35}$ report that $\beta$-lactoglobulin, are considerably less soluble and more sensitive to precipitation by calcium ions than are their native counterparts when denatured.

The degree of heat denaturation of the whey proteins varies depending on the intensity of the thermal treatment of the milk in during the processing of different products. ${ }^{59}$ The kinetics of thermal denaturation of whey proteins is complicated, with a significant effect on the ranges between $80-100{ }^{\circ} \mathrm{C} .{ }^{60}$ The dena- 
turation reaction shows a non-linear Arrhenius relationship; there is a noticeable change dependent on the temperature around 80 $90{ }^{\circ} \mathrm{C}$ for both $\alpha$-LA and $\beta$-LG. The apparent activation energy is in the range of $260-280 \mathrm{~kJ} \cdot \mathrm{mol}^{-1}$ for $\beta-\mathrm{LG}$ and $270-280 \mathrm{~kJ} \cdot \mathrm{mol}^{-1}$ for the $\alpha$-LA at temperatures below $90{ }^{\circ} \mathrm{C} .{ }^{56,57}$ At higher temperatures the activation energy is lower, ranging from 54 to $60 \mathrm{~kJ} \cdot \mathrm{mol}^{-1}$ for $\beta$-LG and 55 to $70 \mathrm{~kJ} \cdot \mathrm{mol}^{-1}$ for the $\alpha$-LA, indicating chemical interactions (aggregation). ${ }^{60}$

Pasteurization or UHT processing causes partial, irreversible unfolding of $\beta$-lactoglobulin, thereby exposing hydrophobic surface and the sulfhydryl group. The subsequent interaction with $x$-casein, stabilized by a sulfhydryl-disulfide interchange, alters the surface properties of casein micelles (Figure 2). ${ }^{55}$ According to Fox 1 the $x$-casein, in particular, has the ability to react with sulfhydryl group of denatured whey proteins, possibly in these form: $[x-\mathrm{CN}]-\mathrm{SH}+\mathrm{HS}-[\beta-$ lactoglobulin $]+\mathrm{O}_{2} \rightarrow[x-\mathrm{CN}]-\mathrm{S}-\mathrm{S}-$ $[\beta$-lactoglobulin $]+\mathrm{H}_{2} \mathrm{O}[x-\mathrm{CN}]-\mathrm{SH}+\mathrm{SS}=[\alpha-\mathrm{La}] \rightarrow[x-\mathrm{CN}]-\mathrm{S}-\mathrm{S}-[\alpha-$ $\mathrm{La}$-SH. These complexes are co-precipitated with caseins when the whey is separated from caseinic phase, resulting in an increase of the $\mathrm{N}$ content and in the size of casein micelles. ${ }^{43}$ Therefore, the heat-induced association of whey protein (especially $\beta$-lactoglobulin) with casein micelles alters micelle properties and also increases heat stability. ${ }^{35}$

Figure 2. MEffect of Heating Milk at $90{ }^{\circ} \mathrm{C}$. The Native $\beta$-lactoglobulin ( $\beta$-LG) Dimer Dissociates and the Monomer Undergoes Internal Disulfide-bond Interchange to Give Reactive Monomers that React with k-casein (k-CN) at the Surface (Outer Region) of the Casein Micelle. Native $\beta$-LG Monomers can also form an Adduct with $\alpha$-lactalbumin $(\alpha-L A)$, which then Gives Rise to $\alpha$-LA Dimers and $\alpha-L A: \beta-L G$ Dimers. In the Severely Heat-treated Samples, as2-CN also forms Disulfide Bonds with Other Proteins 55

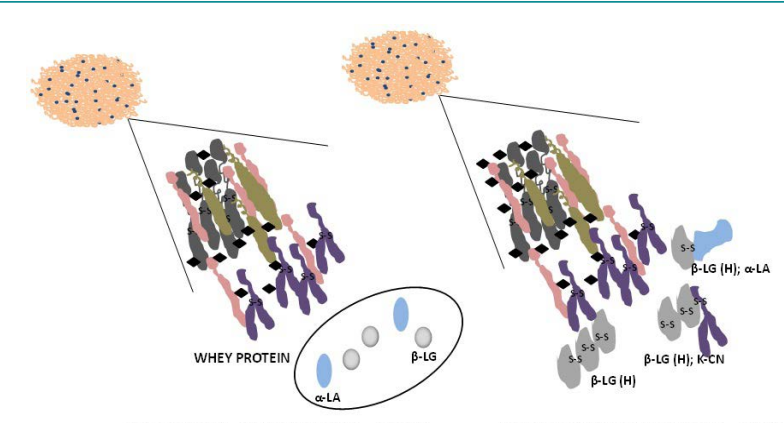

BEFORE HEAT TREATEMENT $(80-100 \stackrel{\circ}{\circ})$

AFTER HEAT TREATEMENT $(80-100 \stackrel{\circ}{\mathrm{C}})$

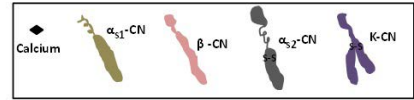

On the other hand, the $\alpha$-lactalbumin does not present $\mathrm{SH}$ groups but present four S-S/mol groups. In order to connect $\alpha$-lactalbumin with the $x$-casein, these S-S groups must first be broken by oxygen. Besides being more heat resistant, the functional group of $\alpha$-lactalbumin is more difficult to connect to the $x$-casein, so it is strongly relevant to the thermal stability of milk. $^{55}$

Oldfield, Singh, and Taylor ${ }^{61}$ suggested that there are at least three possible kinds of denaturation of $\beta$-LG that can as- sociate with the micelles: (i) $\beta$-LG monomer unfolded, (ii) selfaggregating $\beta$-LG and (iii) aggregate LG $\beta$ - $/ \alpha$-LA. The relative association rate of these species with the casein micelles depends on the heating gradient, which in turn affect the relative rates of breakdown and formation of different aggregated species. At higher temperatures and faster heating rates, all whey proteins begin to unfold in a very short period of time, thus presenting an opportunity for more monomers of unfolded $\beta$-LG to auto aggregate, which in turn could make an association with the caseins micelles less efficiently. These $\beta$-LG aggregates could protrude from the surface of the casein micelles promoting a steric effect for new $\beta$-LG associations. Furthermore, these aggregates may have their reactive sulfhydryl groups within the array, and thus unavailable for sulfhydryl-disulfide transfer reactions with $x$-casein micelle. The formation of $\beta$-LG unfolded can be promoted by long periods of heating at low temperature or by heating at a slow rate until the desired temperature. These monomeric molecules of $\beta$-LG enter the capillary layer of $x$-casein and have easier accessibility to the sulfhydryl group.

Besides time and heating temperature, several other factors influence the extent of association of denatured whey proteins with the casein micelles, which include the $\mathrm{pH}$ of the milk prior to heating, the soluble calcium and phosphate concentrations and the concentration of solids in milk. ${ }^{55}$ According to Swaisgood ${ }^{35}$ pasteurization $\left(71.7^{\circ} \mathrm{C}\right.$ for $\left.15 \mathrm{~s}\right)$ or UHT processing $\left(142-150{ }^{\circ} \mathrm{C}\right.$ for $\left.3-6 \mathrm{~s}\right)$ irreversibly increases the amount of colloidal calcium phosphate at the expense of both soluble and ionized calcium and soluble phosphate. Consequently, the $\mathrm{pH}$ also decreases, due to the release of protons from primary and secondary phosphates. The calcium transformed in tertiary calcium phosphate does not come entirely from the serum because heating also causes dissociation of calcium bound to protein. Thus, pasteurization, and especially sterilization, affects the size distribution of micelles, leading to an increase in the abundance of both large and small micelles. Moreover, heat treatments of increasing severity are accompanied by increased production of dehydroalanine residues, due to $\beta$-elimination of disulfide bonds and phosphoseryl residues, increased deamidation of asparaginyl and glutaminyl residues, and increased Maillard browning. Crosslinking of protein during heating can result from the reaction of dehydroalanine residues with $\varepsilon$-amino groups of lysyl residues to form lysinoalanine or reaction with sulfhydryl groups of cysteinyl residues to form lanthionine.

Due to the growing consumer demands for better retention of the nutritional value, sensory attributes, and longer shelf stability of milk, the emerging technologies processes have become more interesting for the dairy industry. ${ }^{62}$ One of these emerging technologies that no present the changes in proteins functionality that the heat treatment presents, is the microfiltration process (MF). ${ }^{63}$ Incorporation of MF in the milk manufacturing process can improve the microbial and sensory quality of milk. ${ }^{31,64}$ Moreover, generally enable high flow rates, improve the yield, reduce the processing costs and shown higher quality compared to conventional heat treatments. ${ }^{62}$ 


\section{Predicting the Effect of Microfiltration on the Properties of Milk} Proteins

The commercial processing of milk are carried out almost entirely by heating temperature processes. ${ }^{62}$ Pasteurized milk currently has a short shelf life (about 14 days) due to the presence of remaining bacteria, ${ }^{65}$ their enzymes ${ }^{66}$ and somatic cells ${ }^{67,68}$ that are not eliminated by this process. On the other hand, UHT treated milk has a longer shelf life, but there is major damage to the molecular structure of milk proteins. It has been reported that heat temperature processes can lead to several changes in milk, including denaturation of whey proteins, the interaction of whey proteins with caseins, inactivation of indigenous enzymes, as well as the destruction of certain nonstarter lactic acid bacteria. ${ }^{22}$ Therefore, as reported by Elwell and Barbano ${ }^{24}$ there is a desire in the fluid milk processing industry for an HTST pasteurization process that will produce fluid milk with a refrigerated shelf life of 60 to 90 days. Nevertheless, there are other technologies currently being researched that may eventually replace the pasteurization or the UHT processes. ${ }^{69}$ These include the membrane filtration process, i.e. microfiltration technologies. ${ }^{70}$

The microfiltration represent an emerging food processing technology in several coutries allowing gentle milk preservation at lower temperatures and shorter treatment times for similar, or better, microbial inactivation and shelf-life stability when applied in a hurdle approach compared to heat temperature processes. ${ }^{62}$ This process is based on the selective permeability of a membrane for one or more of the constituents of the liquid. Selectivity depends on both the type of membrane (different cut-off) and process conditions..$^{70-72}$ The liquid submitted to this process is divided into two fractions: the fluid retained by the membrane (i.e., the retentate), which results in a higher concentration of the components having a bigger size than the average pore diameter of the membrane, and the liquid going through the membrane (i.e., the permeate or the microfiltrate) (Figure 3). ${ }^{73}$

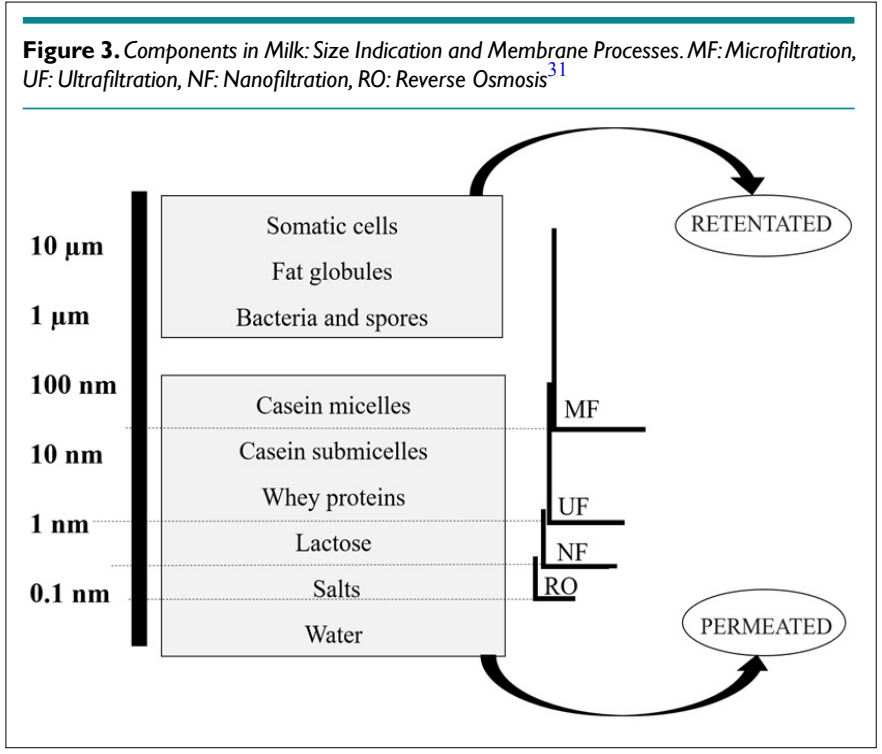

However, as related by Brans et al, ${ }^{31}$ whole milk is a com- plex and challenging feed for microfiltration membranes because of the broad particle size distribution $(1 \mathrm{~nm}-20 \mu \mathrm{m})$ coming from the fat globules and natural and/or seasonal variations in composition. Bacteria spores and somatic cells present in raw milk are not affected by the HTST heat treatment used in the processing of most dairy products, whereas they can be physically removed by microfiltration. If not removed or killed, spores can compromise the quality and shelf life of milk and other dairy products, such as milk powder and cheese. ${ }^{68}$ At the same time, high somatic cells count can lead to increased proteolytic and lipolytic activity in milk, thus compromising the flavor, texture, and shelf life of dairy products. ${ }^{74-77}$ Alternatives to already existing "cold sterilization" processes based on cross-flow microfiltration with ceramic membranes ${ }^{28}$ are being the focus of milk microfiltration. In the case of "cold sterilization", today's commercially available technology based on fine ceramic filters, still has to be combined with final heat treatment in order to guarantee the safety of the final product. Furthermore, due to the fact that the bacteria and spores are smaller than fat globules, the milk needs to be skimmed before the membrane process in order that the microfiltration can be effective against the milk pathogens and spores. ${ }^{78}$ On the other hand, the smaller the ceramic pores, the higher the microbiological quality in the final product but on the process side, unfortunately, more fouling occurs due to milk proteins retention in the membrane and, thus, decreases the productivity of the whole operation. $^{79}$

Membrane processes are used to improve the microbial quality of milk and dairy fluids, as well as are also applied for preserving the functional properties of milk proteins. ${ }^{71}$ Avalli et $\mathrm{al}^{73}$ reported that the mechanic stress of the transmembrane pressure affects minimally the milk proteins in comparison with heat temperature processes. But when the skim milk passes through the microfiltration membrane the proteins and minerals tend to form aggregates in the pores and this problem may decrease the flux and modify its properties and the quantity of the protein in the permeate. ${ }^{80}$ It has been reported that proteins with low internal stability as $\beta-\mathrm{CN}, \alpha-\mathrm{LA}, \mathrm{BSA}$, and immunoglobulin ( $\mathrm{IgG})$ tend to adsorb on all surfaces, even onto electrostatically repelling surfaces. ${ }^{81,82}$ Thus, proteins with diameters much smaller than the membrane pore typically cause pore constriction, while those with a diameter comparable to the membrane pore may cause pore blocking, and proteins larger than the pores can be retained on the membrane surface and cause cake formation. ${ }^{4,83}$ GesanGuiziou et $\mathrm{al}^{84}$ found that as membrane resistance (fouling) increased, the transmission of whey proteins decreased during the MF of skim milk. On the other hand, another membrane property that needs to be considered is it's hydrophilic-hydrophobic character because this is known to affect the strength of the interaction between a protein and a surface. ${ }^{78}$ Specifically, proteins tend to adsorb more extensively and less reversibly at hydrophobic surfaces than at hydrophilic surfaces. ${ }^{85}$ According to Gao et $\mathrm{al}^{86}$ ceramic membranes are hydrophilic and this property does not preclude the deposition of proteins onto its surface. As related by Wang et $\mathrm{al}^{85}$ this behavior may occur because whereas proteins tend to unfold and spread their hydrophobic core over hydrophobic surfaces, their charged and polar functional groups 
tend to interact with hydrophilic surfaces. In the case of $\mathrm{CN}$ micelles, it is known that the hydrophilic ends of $x$-CN molecules are preferentially located at the surface of micelles, which would explain the ceramic membrane- $\mathrm{CN}$ interactions. ${ }^{78}$

Investigations on the minor whey protein bovine serum albumin (BSA) conducted by Chandavarkar ${ }^{87}$ and Kim et $\mathrm{al}^{88}$ have shown that protein aggregates are formed in shear flow during cross-flow filtration, which is deposited on the membrane surface afterward. In contrast to BSA, the major membrane foulant during whey filtration, $\beta-\mathrm{Lg}$, is not sensitive to shear forces. ${ }^{89}$ Kelly, Opong, and Zydney, ${ }^{90}$ as well as Kelly and Zydney ${ }^{91}$ and Kelly and Zydney, ${ }^{92}$ found that BSA-aggregates catalyze fouling when deposited on the membrane. The molecular mechanism involved in the fouling reaction was found to be based on the exposure of reactive thiol-groups in the deposit. This reactive initial deposit then serves as a nucleation site for further thiol oxidation and thiol-interchange reactions. Despite the fact that the proteins varied significantly in size, molecular structure and originated from various animal protein sources (Table 2), Kelly and Zyndey ${ }^{93}$ observed that intensity of membrane fouling was correlated to the number of free thiols of the respective protein (Figure 4).

\begin{tabular}{|c|c|c|c|c|c|c|}
\hline Protein & $\begin{array}{l}\text { Size } \\
(k D a)\end{array}$ & $\mathrm{pl}$ & $-\mathrm{SH}$ & -S-S- & $\begin{array}{l}\text { Concentration } \\
\text { in whey }(\mathrm{g} / \mathrm{L})\end{array}$ & $\begin{array}{l}\text { Mass } \\
\text { portion (\%) }\end{array}$ \\
\hline$\beta$-Lactoglobulin & 18.3 & 5.13 & 1 & 2 & 3 & 60 \\
\hline$\alpha$-Lactalbumin & 14.2 & $4.2-4.5$ & 0 & 4 & 1.2 & 20 \\
\hline $\begin{array}{l}\text { Bovine serum } \\
\text { albumin }\end{array}$ & 66.4 & 4.7 & I & 17 & 0.4 & 3 \\
\hline Immunoglobulin G & 161 & - & - & - & 0.6 & 10 \\
\hline Lactoferrin & 76.1 & 9 & 0 & 17 & 0.02 & $<0.1$ \\
\hline
\end{tabular}

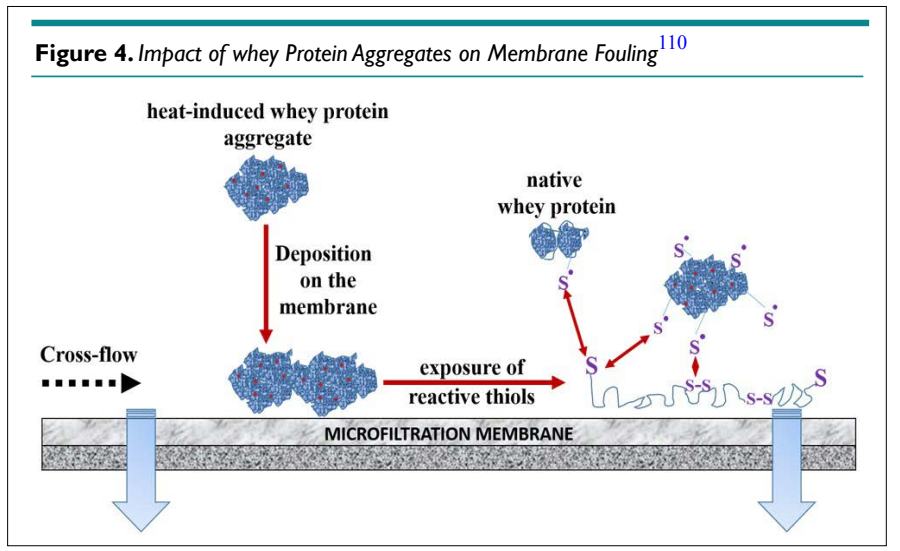

Like as BSA, $\beta-\mathrm{Lg}$ contains one free sulfhydryl group (Table 2). Hence, membrane fouling based on thiol-interchange reactions as well as thiol oxidation probably also applies for $\beta-\mathrm{Lg}$ or other whey proteins. This reaction pathway via thiol/disulfide reactions is known for $\beta-\mathrm{Lg}$ aggregation during thermal processing. ${ }^{94}$ Additionally, for the major whey protein $\beta$-Lg it was found that gel network formation is facilitated in the presence of calcium. ${ }^{95,96}$ Based on this, Marshall, Munro, and Trägårdh ${ }^{97}$ assumed that calcium-induced cross-linking was involved in $\beta$-Lg deposit formation. $^{98}$

Besides these properties, Kühnl et al ${ }^{99}$ related that the microfiltration flux during cross-flow filtration depends on the $\mathrm{pH}$ of milk and showed that the casein micelles where size constant in the $\mathrm{pH}$ 5.9-6.8 range. Acidification of milk from $\mathrm{pH} 6.8$ to 5.9 leads to a strong reduction of hydrophilic repulsion between casein micelles while the micelle size remains the same. ${ }^{99}$ In addition to acidification, this behavior can also be described by a model which incorporates van der Waals and electrostatic interactions as well as hydrophilic and hydrophobic Lewis AcidBase interactions. In accordance, Steinhauer et $\mathrm{al}^{4}$ reported that a less repulsion between casein micelles, in turn, results in a flux drop, i.e. that change in colloidal interaction is a basic problem in cross-flow filtration.

In addition, minerals are found in association with casein, whey protein, and fat globule membranes. ${ }^{35}$ Furthermore, the minerals in the whey phase of milk are present as free ions, salts, or in association with whey proteins. According to Svanborg et $a{ }^{100}$ these minerals may pass through the MF membrane, and their distribution after MF fractionation will influence the functional properties of the fractions. For example, the treatment of milk with MF will increase the calcium (Ca) content and the buffering capacity of the retentate, therefore delaying the $\mathrm{pH}$ reduction during traditional cheese making. ${ }^{101}$ As reported by Kaombe et $\mathrm{al}^{102}$ for pasteurized milk, the temperature of the MF process also may influence the $\mathrm{Ca}$ content on dialysates and permeates. On the other hand, even relatively mild heat treatments, such as HTST, could most likely affect the composition and protein yield of the MF permeate. Increasing the temperature is expected to decrease the viscosity of the permeate, ${ }^{103}$ and if no change in membrane resistance occurs the transmembrane pressure required to maintain a constant flux is expected to decrease as the temperature is increased. ${ }^{104}$ Moreover, heat denaturation of whey proteins may also change the performance of the membranes during MF. ${ }^{100}$

Hurt et al ${ }^{104}$ clarified that increasing the temperature of MF from 50 to $65{ }^{\circ} \mathrm{C}$ could also cause denaturation of whey proteins and possible association with casein $(\mathrm{CN})$ micelles. Long et $\mathrm{al}^{105}$ reported that only $3.4 \%$ of $\beta$-Lactoglobulin was associated with $x$-CN after $20 \mathrm{~min}$ at $65^{\circ} \mathrm{C}$, and thus when they was covalently associated, the yield of whey protein in the permeate would be reduced. In addition, aggregates of $\beta$-LG and $\alpha$-LA have also been found when heated at $75^{\circ} \mathrm{C}$, ${ }^{106}$ being unable to pass through the MF membrane. It was shown that whey protein hydrophobicity increases as a consequence of protein unfolding, e.g. under heat-treatment. ${ }^{107}$ Another reason for protein unfolding and an increase in hydrophobicity is surface denaturation, as it is reported for the adsorption of several proteins including $\beta-L G$ at hydrophobic surfaces. Unfolding was found to increase when repulsive electrostatic interaction forces were reduced. ${ }^{108}$ It can be assumed that hydrophobic whey protein aggregates can potentially serve as adsorption sites and induce protein unfolding during deposit layer formation on membranes. Steinhauer et al ${ }^{109}$ confirm that $\beta$-LG and its heat-induced aggregates are the major 
Mcsweeney PLH, eds. Encyclopedia of Dairy Sciences, $2^{\text {nd }}$ ed. Cambridge, Massachusetts, USA: Academic Press; 2011: 18-25. ly reactive deposit and accelerate membrane fouling (Figure 4). Therefore, deposited aggregates serve as nucleation sites for thiol oxidation and disulfide reactions between deposited particles and native protein. Some works confirm this theory since aggregates formed during whey heat-treatment enhance membrane fouling. . $^{97110-112}$

Briefly, the microfiltration is an emerging technology that can improve the quality of milk and dairy products once that changes in protein properties do not occur as far as in milk produced by heat treatments. The most important reactions that occur during milk heat treatment are the protein denaturation of whey proteins, its interactions with the casein micelles and aggregation/dissociation of the casein micelles. The microfiltration also has the advantages of retaining spores of microorganisms and somatic cells that no are affected by heat treatments, that can damage the milk and dairy products quality and safety. However, the microfiltration, considerate a mechanical process, makes that the milk continues to be considered raw and in Brazil (as in other countries) is not possible to sell raw milk. On the other hand, heat treatments are the established food technology for commercial processing of milk in order to provide acceptable safety and shelf life. The shelf life of pasteurized milk in around 8 days while for the microfiltrated milk is close to 30 days. ${ }^{113}$ Finally, how is not possible yet to produce only microfiltered milk in Brazil, several works recommend the use of the two technologies (microfiltration and pasteurization) for preserving the better as is possible the quality of the milk proteins and the others constituents. ${ }^{62,114}$

\section{Final Considerations}

The microfiltration, a mechanical process, affects minimally the properties of milk proteins as compared to heat treatments. However, only the use of membrane filtration process is not completely understood since the microbiological quality cannot always be guaranteed, and these may bring some disadvantages to the consumer. Therefore, more studies regarding the microbiological safety of microfiltered milk must be performed in several countries. On the other hand, the heat treatment in the fluid milk technologies is already established in the industry worldwide. Despite the negative influence on the milk proteins, it is a safer methodology to produce this kind of products nowadays. The use of heat treatment prior to microfiltration may induce a higher membrane fouling because of the formation of protein aggregates. Meanwhile, microfiltration in combination with pasteurization can be an alternative to extend the shelf life of pasteurized milk by removal microorganisms, spores, and somatic cells of raw milk.

\section{CONFLICTS OF INTEREST |}

The authors declare that they have no conflicts of interest.

\section{REFERENCES}

1. Fox PF. History of dairy chemistry. In: Fuquay JW, Fox PF,
2. Damodaran S. Aminoácido S, Peptídeos E Proteínas. In: Damodaran S, Parkin KL, Fennema OR, eds. Quimica De Alimentos De Fennema, $4^{\text {th }}$ ed. Porto Alegre, Canada: Artmed; 2010.

3. Foegeding EA, Davis JP, Doucet D, Mcguffey MK. Advances in modifying and understanding whey protein functionality. Trends in Food Science and Technology. 2002; 13: 151-159. doi: 10.1016/S09242244(02)00111-5

4. Steinhauer T, Kühnl W, Kulozik U. Impact of protein interactions and transmembrane pressure on physical properties of filter cakes formed during filtrations of skim milk. Procedia Food Science. 2011; 1: 886-892. doi: 10.1016/j.profoo.2011.09.134

5. Fox PF, Mcsweeney PLH. Milk proteins. In: Fox PF, McSweeney PLH. eds. Dairy Chemistry and Biochemistry. New York, USA: Blackie Academic \& Professional; 1998: 146-237.

6. Farrell HM. Casein nomenclature, structure, and association. In: Fuquay JW, Fox PF, Mcsweeney PLH, eds. Encyclopedia of Dairy Sciences. $2^{\text {nd }}$ ed. Cambridge, Massachusetts, USA: Academic Press; 2011: 765-771.

7. Walstra P, Wouters JT, Geurts TJ. Dairy Science and Technology. $2^{\text {nd }}$ ed. Oxfordshire, UK: Taylor \& Francis Group; 2006.

8. Burton H. Ultra-High-Temperature Processing of Milk and Milk Products. New York, USA: Elsevier Applied Science Publishers; 1988.

9. Mottar J, Naudts M. La qualité du lait chauffé à ultrahaute température comparée à celle du lait pasteurisé et stérilisé dans la bouteille. Lait. 1979; 59: 476-488. doi: 10.1051/lait:197958823

10. Burton, H. Reviews of the progress of dairy science: the bacteriological, chemical, biochemical and physical changes that occur in milk at temperatures of 100-150 degrees C. Journal of Dairy Research. 1984; 51: 341-363.

11. Cheeseman GC, Knight DC. The nature of casein aggregates in heated and stored milk. Journal of Dairy Research. 1974; 41: 359366. doi: 10.1017/S0022029900019804

12. Douglas FW, Greenberg Jr. R, Farrell Jr, HM, Edmondson LF. Effects of ultra-high-temperature pasteurization on milk proteins. Journal of Agricultural and Food Chemistry. 1981; 29: 11-15. doi: 10.1021/jf00103a004

13. Singh H, Latham JM. Heat stability of milk: Aggregation and dissociation of protein at ultra-high temperatures. International Dairy Journal. 1993; 3: 225-237. doi: 10.1016/09586946(93)90066-9

14. Cosio MS, Mannino S, Buratti S. Electrochemical sensor 
detecting free sulfhydryl groups: Evaluation of milk heat treatment. J Dairy Sci. 2000; 83: 1933-1938. doi: 10.3168/jds.S00220302(00)75068-5

15. Elliott AJ, Datta N, Amenu B, Deeth HC. Heat-induced and other chemical changes in commercial UHT milks. J Dairy Res. 2005; 72: 442-446. doi: 10.1017/S002202990500138X

16. Pellegrino L, De Noni I, Resmini P. Coupling of lactulose and furosine indices for quality evaluation of sterilized milk. International Dairy Journal. 1995; 5: 647-659. doi: 10.1016/09586946(95)00036-3

17. Borcherding K, Lorenzen PC, Hoffmann W, Schrader K. Effect of foaming temperature and varying time/temperature conditions of pre-heating on the foaming properties of skimmed milk. International Dairy Journal. 2008; 18: 349-358. doi: 10.1016/j. idairyj.2007.11.016

18. Krasaekoopt W, Bhandari B, Deeth H. Yogurt from UHT milk: A review. Australian Journal of Dairy Technology. 2003; 58: 2629.

19. Parnell-Clunies E, Kakuda Y, Deman JM, Cazzola F. Gelation profiles of yogurt as affected by heat treatment of milk. J Dairy Sci. 1988; 71: 582-588. doi: 10.3168/jds.S0022-0302(88)79594-6

20. Wang Q, Bulca S, Kulozik U. A comparison of low-intensity ultrasound and oscillating rheology to assess the renneting properties of casein solutions after UHT heat pre-treatment. International Dairy Journal. 2007; 17: 50-58. doi: 10.1016/j.idairyj.2005.12.008

21. Al-Akoum O, Ding LH, Jaffrin MY. Microfiltration and ultrafiltration of UHT skim milk with a vibrating membrane module. Separation and Purification Technology. 2002; 28: 219-234. doi: 10.1016/S1383-5866(02)00076-X

22. Amornkul Y, Henning DR. Utilization of microfiltration or lactoperoxidase system or both for manufacture of cheddar cheese from raw milk. J Dairy Sci. 2007; 90: 4988-5000. doi: $10.3168 /$ jds.2007-0281

23. Carvalho AF, Maubois JL. Applications of membrane technologies in the dairy industry. In: Coimbra JSR, Teixeira JA, eds. Engineering Aspects of Milk and Dairy Products. Boca Raton, Florida, USA: CRC Press; 2009: 33-56.

24. Elwell MW, Barbano DM. Use of microfiltration to improve fluid milk quality. J Dairy Sci. 2006; 89: 20-30. doi: 10.3168/jds. S0022-0302(06)72361-X

25. Fritsch J, Moraru CI. Development and optimization of carbon dioxideaided cold microfiltration process for the physical removal of microorganisms and somatic cells from skim milk. $J$ Dairy Sci. 2008; 91: 3744-3760. doi: 10.3168/jds.2007-0899
26. Larsen PH. Microfiltration for pasteurised milk. In: Fox PF, ed. Heat Treatments and Alternative Methods. Belgium: International Dairy Federation; 1995: 232-239.

27. Meershon M. Nitrate free cheesemaking with bactocatch. North European Food Dairy Journal. 1989; 55: 108-113.

28. Saboya LV, Maubois JL. Current developments of microfiltration technology in the dairy industry. Lait. 2000; 80: 541-553. doi: 10.1051/lait:2000144

29. Trouve E, Maubois JL, Piot M, et al. Rètention de différentesespécesmicrobienneslors de l'epuration du lait par microfiltration en flux tangentiel. Lait. 1991; 71: 1-13.

30. Amelia I, Barbano DM. Production of an $18 \%$ protein liquid micellar casein concentrate with a long refrigerated shelf life. $J$ Dairy Sci. 2013; 96: 3340-3349. doi: 10.3168/jds.2012-6033

31. Brans G, Schroën CGPH, Van Der Sman RGM, Boom RM. Membrane fractionation of milk: State of the art and challenges. Journal of Membrane Science. 2004; 243: 263-272.

32. Papadatos A, Neocleous M, Berger AM, Barbano DM. Economic feasibility evaluation of microfiltration of milk prior to cheesemaking. J Dairy Sci. 2003; 86: 1564-1577. doi: 10.3168/jds. S0022-0302(03)73742-4

33. Messens W, Camp V, Huyghebaert A. The use of high pressure to modify the functionality of food proteins. Trends in Food Science and Technology. 1997; 8: 107-112. doi: 10.1016/S09242244(97)01015-7

34. Foegeding EA, Davis JP. Food protein functionality: A comprehensive approach. Food Hydrocolloids. 2011; 25: 1853-1864. doi: 10.1016/j.foodhyd.2011.05.008

35. Swaisgood HE. Características do leite. In: Damodaran S, Parkin KL, Fennema OR, eds. Quimica De Alimentos De Fennema. $4^{\text {th }}$ ed. Porto Alegre: Artmed. 2010.

36. De Kruif CG, Huppertz T, Urban VS, Petukhov AV. Casein micelles and their internal structure. Adv Colloid Interface Sci. 2012; 171: 36-52. doi: 10.1016/j.cis.2012.01.002

37. De Kruif CG, Holt C. Casein micelle structure, functions and interactions. In: Fox PF, McSweeney PLH, eds. Advanced Dairy Chemistry, $3^{\text {rd }}$ ed. New York, USA: Kluwer Academic/Plenum Publishers; 2003: 233-276.

38. Swaisgood HE. Symposium: Genetic perspectives on milk proteins: Comparative studies and nomenclature. Review and update of casein chemistry. J Dairy Sci. 1993; 76: 3054-3060.

39. Raikos V. Effect of heat treatment on milk protein functionality at emulsion interfaces: A review. Food Hydrocolloids. 2010; 24: 259-265. doi: 10.1016/j.foodhyd.2009.10.014 
40. Baier D, Schmitt C, Knorr D. Effect of high pressure - low temperature processing on composition and colloidal stability of casein micelles and whey proteins. International Dairy Journal. 2015; 43: 51-60. doi: 10.1016/j.idairyj.2014.11.008

41. Crowley P, O’Brien CM, Slattery H, Chapman D, Arendt EK, Stanton C. Functional properties of casein hydrolysates in bakery applications. European Food Research and Technology. 2002; 215: 131 137. doi: $10.1007 /$ s00217-002-0510-5

42. Erdem YK. Modification of casein micelle structure caused by ultrafiltration and heat treatment: A spectrofluorimetric and kinetic approach. Journal of Food Engineering. 2006; 74: 536-541. doi: 10.1016/j.jfoodeng.2005.03.041

43. Considine T, Patel HA, Anema SG, Singh H, Creamer LK. Interactions of milk proteins during heat and high hydrostatic pressure treatments - A review. Innovative Food Science and Emerging Technologies. 2007; 8: 1-23. doi: 10.1016/j.ifset.2006.08.003

44. Kuwajima K, Ikeguchi M, Sugawara T, Hiraoka Y, Sugai S. Kinetics of disulfide bond reduction in $\alpha$-lactalbumin by dithiothreitol and molecular basis of superreactivity of the cys 6 -cys 120 disulfide bond. Biochemistry. 1990; 29: 8240-8249. doi: 10.1021/ bi00488a007

45. Wijayanti HB, Bansal N, Deeth HC. Stability of whey proteins during thermal processing: A review. Comprehensives Reviews in Food Science and Food Safety. 2014; 13: 1235-1251. doi: 10.1111/15414337.12105

46. Angel CR, Dalgleish DG. Structures and some properties of soluble protein complexes formed by the heating of reconstituted skim milk powder. Food Research International. 2006; 39: 472 479. doi: 10.1016/j.foodres.2005.09.010

47. Gani A, Broadway AA, Ahamd M, et al. Effect of whey and casein protein hydrolysates on rheological, textural and sensory properties of cookies. J Food Sci Technol. 2014; 35: 1-9. doi: 10.1007/s13197-014-1649-3

48. Singh H, Waungana A. Influence of heat treatment of milk on cheesemaking properties. International Dairy Journal. 2001; 11: 543-551. doi: 10.1016/S0958-6946(01)00085-1

49. Nicorescu I, Loisel C, Vial C, et al. Combined effect of dynamic heat treatment and ionic strength on the properties of whey protein foams - Part II. Food Research International. 2008; 41: 980-988. doi: 10.1016/j.foodres.2008.08.003

50. Jelen P, Rattray W. Thermal denaturation of whey proteins. In: Fox PF, ed. Heat-Induced Changes in Milk. $2^{\text {nd }}$ ed. Belgium: International Dairy Federation; 1995: 66-85.

51. Pellegrino L, Cattaneo S, De Noni I. Effects of processing on protein quality of milk and milk products. In: Fuquay JW, Fox PF, Mcsweeney PLH, eds. Encyclopedia of Dairy Sciences. $2^{\text {nd }}$ ed. Cam- bridge, Massachusetts, USA: Academic Press; 2011: 226-234.

52. Kinsella JE. Relationships between structure and functional properties of food proteins. In: Fox PF, Condon JJ. Food Proteins. New York, USA: Applied Science; 1982: 51-103.

53. Corredig M, Dalgleish DG. Effect of different heat treatments on the strong binding interactions between whey proteins and milk fat globules in whole milk. Journal of Dairy Research. 1996; 63: 441-449. doi: 10.1017/S0022029900031940

54. Jeanson S, Dupont D, Grattard N, Rolet-Répécaud O. Characterization of the heat treatment undergone by milk using two inhibition ELISAs for quantification of native and heat denatured $\alpha$-Lactalbumin. J Agric Food Chem. 1999; 47: 2249-2254. doi: $10.1021 /$ jf9809232

55. Patel HA, Singh H, Anema SG, Creamer LK. Effects of heat and high hydrostatic pressure treatments on disulfide bonding interchanges among the proteins in skim milk. J Agric Food Chem. 2006; 54: 3409-3420. doi: 10.1021/jf052834c

56. Dannenberg F, Kessler HG. Reaction kinetics of the denaturation of whey proteins in milk. Journal of Food Science. 1998; 53: 258-263. doi: 10.1111/j.1365-2621.1988.tb10223.x

57. Oldfield DJ, Singh H, Taylor MW, Pearce KN. Kinetics of denaturation and aggregation of whey proteins in skim milk heated in an ultra-hight temperature (UHT) pilot plant. International Dairy Journal. 1998; 8: 311-318. doi: 10.1016/S0958-6946(98)00089-2

58. Singh H, Creamer LK. Heat stability of milk. In: FOX PF. Advanced Dairy Chemistry. $2^{\text {nd }}$ ed. Barking, London: Elsevier Applied Science; 1992: 621-656.

59. Wolfschoon-Pombo AF, Fernandes RM, Granzinolli GGM. Efeitos da pasteurizacao-HTST e da fervura domestica sobre a proteína do leite [In: French]. Revista do Instituto de Laticinios Cândido Tostes. 1982; 37: 3-7.

60. Claeys WL, Ludikhuyze LR, Van Loey AM, Hendrickx ME. Inactivation kinetics of alkaline phosphatase and lactoperoxidase, and denaturation kinetics of $\beta$-lactoglobulin in raw milk under isothermal and dynamic temperature conditions. J Dairy Res. 2001; 68: 95-107.

61. Oldfield DJ, Singh H, Taylor MW. Association of $\beta$-lactoglobulin and $\alpha$-lactalbumin whit the casein micelles in skim milk heated in an ultra-hight temperature plant. International Dairy Journal. 1998; 8: 765-770. doi: 10.1016/S0958-6946(98)00127-7

62. Walkling-Ribeiro M, Rodríguez-González O, Jayaram S, Griffiths MW. Microbial inactivation and shelf life comparison of 'cold' hurdle processing with pulsed electric fields and microfiltration, and conventional thermal pasteurisation in skim milk. Int J Food Microbiol. 2011; 144: 379-386. doi: 10.1016/j.ijfoodmicro. 2010.10 .023 
2004; 389: 49-53.

63. Hoffmann W, Kiesner C, Clawin-Raedecker I, et al. Processing of extended shelf life milk using microfiltration. International Journal of Dairy Technology. 2006; 59: 229-235. doi: 10.1111/j.14710307.2006.00275.x

64. Kaufmann V, Kulozik U. Kombination von mikrofiltration und thermischen verfahrenzur haltbarkeits verlängerung von lebensmitteln. Chemie Ingenieur Technik. 2006; 78: 1647-1654. doi: $10.1002 /$ cite. 200600094

65. Fernández García L, Álvarez Blanco S, Riera Rodríguez FA. Microfiltration applied to dairy streams: Removal of bacteria. $J$ Sci Food Agric. 2013; 93(2): 187-196. doi: 10.1002/jsfa.5935

66. Fromm HI, Boor KJ. Characterization of pasteurized fluid milk shelf-life attributes. Journal of Food Science. 2004; 69: 207-214. doi: 10.1111/j.1365-2621.2004.tb09889.x

67. Barbano DM, Ma Y, Santos MV. Influence of raw milk quality on fluid milk shelf life. J Dairy Sci. 2006; 89 Suppl 1: E15-19. doi: 10.3168/jds.S0022-0302(06)72360-8

68. Gesan-Guiziou G. Removal of bacteria, spores and somatic cells from milk by centrifugation and microfiltration techniques. In: Griffiths MW, ed. Improving the Safety and Quality of Milk. Sawston, Cambridge: Woodhead Publishing; 2010: 349-372.

69. Pouliot Y. Membrane processes in dairy technology_-From a simple idea to worldwide panacea. International Dairy Journal. 2008; 18: 735-740. doi: 10.1016/j.idairyj.2008.03.005

70. Baker RW. Membrane Technology and Applications. $2^{\text {nd }}$ ed. New York, USA: John Wiley and Sons; 2004: 538.

71. Rosenberg M. Current and future applications for membrane processes in the dairy industry. Trends in Food and Technology. 1995; 6: 12-19. doi: 10.1016/S0924-2244(00)88912-8

72. Wiston WS, Sirkar KK. Membrane Handbook. New York, USA: Springer Publishers; 1992: 3-16.

73. Avalli A, Povolo M, Carminati D, Contarini GA. Significance of 2-heptanone in evaluating the effect of microfiltration/pasteurisation applied to goats' milk. International Dairy Journal. 2004; 14: 915-921. doi: 10.1016/j.idairyj.2004.03.004

74. Azzara CD, Dimick PS. Lipoprotein lipase activity of milk from cows with prolonged subclinical mastitis. J Dairy Sci. 1985; 68: 3171-3175. doi: 10.3168/jds.S0022-0302(85)81223-6

75. Ma Y, Ryan C, Barbano DM, et al. Effects of somatic cell count on quality and shelf-life of pasteurized fluid milk. J Dairy Sci. 2000; 83: 264-274. doi: 10.3168/jds.S0022-0302(00)74873-9

76. Te Giffel MC, Van Der Horst HC. Comparison between bactofugation and microfiltration regarding efficiency of somatic cell and bacteria removal. Bulletin of the International Dairy Federation.
77. Verdi RJ, Barbano DM. Preliminary investigation of the properties of somatic cell proteases. J Dairy Sci. 1988; 71: 534-538. doi: 10.3168/jds.S0022-0302(88)79586-7

78. Tan TJ, Wang D, Moraru CI. A physicochemical investigation of membrane fouling in cold microfiltration of skim milk. J Dairy Sci. 2014; 97(8): 4759-4771. doi: 10.3168/jds.2014-7957

79. Fuente EBL, Torrestiana-Sanchez B, Martínez-Gonzalez E, Mainou-Sierra JM. Microfiltration of whole milk with silicon microsieves: Effect of process variables. Chemical Engineering Research and Design. 2010; 88: 653-660. doi: 10.1016/j.cherd.2009.09.014

80. James BJ, Jing Y, Chen XD. Membrane fouling during filtration of milk-A microstructural study. Journal of Food Engineering. 2003; 60: 431-437. doi: 10.1016/S0260-8774(03)00066-9

81. Dickinson, E. Adsorbed protein layers at fluid interfaces: Interactions, structure and surface rheology. Colloids and Surfaces B: Biointerfaces. 1999; 15: 161-176. doi: 10.1016/S0927-7765(99)00042-9

82. Nakanishi K, Sakiyama T, Imamura K. On the adsorption of proteins on solid surfaces, a common but very complicated phenomenon. J Biosci Bioeng. 2001; 91(3): 233-244. doi: 10.1016/ S1389-1723(01)80127-4

83. Fane AG, Chang S. Techniques to enhance performance of membrane processes. In: Pabby AK, Rizvi SSH, Sastre AM. Handbook of Membrane Separations: Chemical, Pharmaceutical, Food, and Biotechnological Applications. Boca Raton, Florida: CRC Press; 2009: 193-232.

84. Gesan-Guiziou G, Boyaval E, Daufin G. Critical stability conditions in crossflow microfiltration of skim milk: Transition to irreversible fouling. Journal of Membrane Science. 1999; 158: 211-222. doi: 10.1016/S0376-7388(99)00017-4

85. Wang K, Zhou C, HongY, Zhang X. A review of protein adsorption on bioceramics. Interface Focus. 2012; 2: 259-277. doi: $10.1098 /$ rsfs.2012.0012

86. Gao N, Li M, Jing W, Fan Y, Xu N. Improving the filtration performance of $\mathrm{ZrO}_{2}$ membrane in non-polar organic solvents by surface hydrophobic modification. Journal of Membrane Science. 2011; 375: 276-283. doi: 10.1016/j.memsci.2011.03.056

87. Chandavarkar AS. Dynamics of fouling of microporous membranes by proteins. United States. Massachusetts Institute of Technology. 1990; 274-284.

88. Kim KJ, Chen V, Fane AG. Some factors determining protein aggregation during ultrafiltration. Biotechnol Bioeng. 1993; 42: 260 265. doi: $10.1002 /$ bit. 260420216

89. Jaspe J, Hagen SJ. Do protein molecules unfold in a simple 
shear flow? Biophys J. 2006; 91: 3415-3424. doi: 10.1529/biophysj.106.089367

90. Kelly ST, Opong WS, Zydney AL. The influence of protein aggregates on the fouling of microfiltration membranes during stirred cell filtration. Journal of Membrane Science. 1993; 80: 175187. doi: 10.1016/0376-7388(93)85142-J

91. Kelly ST, Zydney AL. Effects of intermolecular thiol-disulfide interchange reactions on BSA fouling during microfiltration. Biotechnol Bioeng. 1994; 44: 972-982. doi: 10.1002/bit.260440814

92. Kelly ST, Zydney AL. Mechanisms for BSA fouling during microfiltration. Journal of Membrane Science. 1995; 107: 115-127. doi: 10.1016/0376-7388(95)00108-O

93. Kelly ST, Zydney AL. Protein fouling during microfiltration: Comparative behavior of different model proteins. Biotechnol Bioeng, 1997; 55: 91-100. doi: 10.1002/(SICI)10970290(19970705)55:1<91::AID-BIT11>3.0.CO;2-6

94. Wit JN. Thermal behaviour of bovine $\beta$-lactoglobulin at temperatures up to 150C. A review. Trends in Food Science Technology. 2009; 20: 27-34. doi: 10.1016/j.tifs.2008.09.012

95. Barbut S, Foegeding EA. $\mathrm{Ca}^{2+}$-induced gelation of pre-heated whey protein isolate. Journal of Food Science. 1993; 58: 867-871. doi: 10.1111/j.1365-2621.1993.tb09379.x

96. Xiong YL, Dawson KA, Wan L. Thermal aggregation of $\beta$-lactoglobulin: Effect of $\mathrm{pH}$, ionic environment, and thiol reagent. J Dairy Sci. 1993; 76: 70-77. doi: 10.3168/jds.S00220302(93)77324-5

97. Marshall AD, Munro PA, Trägårdh G. Influence of ionic calcium concentration on fouling during the cross-flow microfiltration of $\beta$-lactoglobulin solutions. Journal of Membrane Science. 2003; 217: 131-140. doi: 10.1016/S0376-7388(03)00085-1

98. Edwards PB, Creamer LK, Jameson GB. Structure and stability of whey proteins. In: Boland M, Singh H, Thompson A. Milk Proteins. Amsterdam, Netherlands: Elsevier; 2008: 163-203.

99. Kühnl W, Piry A, Kaufmann V, Grein T, Ripperger S, Kulozik U. Impact of colloidal interactions on the flux in cross-flow microfiltration of milk at different $\mathrm{pH}$ values: A surface energy approach. Journal of Membrane Science. 2010; 352: 107-115. doi: 10.1016/j.memsci.2010.02.006

100. Svanborg S, Johansen AG, Abrahamsen RK, Skeie SB. Initial pasteurization effects on the protein fractionation of skimmed milk by microfiltration. International Dairy Journal. 2014; 37: 26-30. doi: 10.1016/j.idairyj.2014.02.004

101. McMahon DJ, Paulson B, Oberg CJ. Influence of calcium, $\mathrm{pH}$, and moisture on protein matrix structure and functionality in direct-acidified nonfat Mozzarella cheese. J Dairy Sci. 2005; 88:
3754-3763. doi: 10.3168/jds.S0022-0302(05)73061-7

102. Kaombe DD, Du YH, Lewis MJ. Mineral partitioning in milk and milk permeates at high temperature. J Dairy Res. 2012; 79: 1-6. doi: 10.1017/S0022029911000616

103. Morison KR, Mackay FM. Viscosity of lactose and whey protein solutions. International Journal of Food Properties. 2001; 4: 441-454. doi: 10.1081/JFP-100108647

104. Hurt EE, Adams MC, Barbano DM. Microfiltration of skim milk and modified skim milk using a $0.1-\mu \mathrm{m}$ ceramic uniform transmembrane pressure system at temperatures of 50, 55, 60, and $65^{\circ} \mathrm{C}$. J Dairy Sci. 2015; 98(2): 765-780. doi: 10.3168/ jds.2014-8775

105. Long JE, Van Winkle Q, Gould JA. Heat-induced interaction between crude $x$-casein and $\beta$-lactoglobulin. J Dairy Sci. 1963; 46: 1393-1396. doi: 10.3168/jds.S0022-0302(63)89276-0

106. Dalgleish DG, Senaratne V, Francois S. Interactions between $\alpha$-lactalbumin and $\beta$-lactoglobulin in the early stages of heat denaturation. Journal of Agricultural and Food Chemistry. 1997; 45: 3459-3464. doi: 10.1021/jf970113a

107. Moro A, Gatti C, Delorenzi N. Hydrophobicity of whey protein concentrates measured by fluorescence quenching and its relation with surface functional properties. J Agric Food Chem. 2001; 49: 4784-4789. doi: 10.1021/jf001132e

108. Wu X, Narsimhan G. Characterization of secondary and tertiary conformational changes of beta-lactoglobulin adsorbed on silica nanoparticle surfaces. Langmuir. 2008; 24: 4989-4998. doi: 10.1021/la703349c

109. Steinhauer T, Schwing J, Krauß S, Kulozik U. Enhancement of ultrafiltration performance and improvement of hygienic quality during the production of whey concentrates. International Dairy Journal. 2015; 45: 8-14. doi: 10.1016/j.idairyj.2015.01.010

110. Marshall AD, Munro PA, Trägårdh G. Influence of permeate flux on fouling during the microfiltration of $\beta$-lactoglobulin solutions under cross-flow conditions. Journal of Membrane Science. 1997; 130: 23-30. doi: 10.1016/S0376-7388(97)00004-5

111. Mourouzidis-Mourouzis S, Karabelas A. Whey protein fouling of microfiltration ceramic membranes-pressure effects. Journal of Membrane Science. 2006; 282: 124-132. doi: 10.1016/j. memsci.2006.05.012

112. Mourouzidis-Mourouzis S, Karabelas A. Whey protein fouling of large poresize ceramic microfiltration membranes at small cross-flow velocity. Journal of Membrane Science. 2008; 323: 17-27. doi: 10.1016/j.memsci.2008.05.053

113. Pinto MS, Pires ACS, Sant'ana HMP, Soares NFF, Carvalho AF. Influence of multilayer packaging and microfiltration process 
on milk shelf life. Food Packaging and Shelf Life. 2014; 1:151-159. 114. Lewis M. Improving pasteurized and extended shelf-life doi: 10.1016/j.fpsl.2014.01.006 milk. In: Griffiths MW, ed. Improving the Safety and Quality of Milk. Sawston, Cambridge: Woodhead Publishing; 2010: 277-301. 